\title{
Sistem Robot Penyelamat Menggunakan Metode Deteksi Viola-Jones untuk Membantu Tim Pencarian dan Penyelamatan Menemukan Korban Bencana
}

\author{
Ardiansyah Al Farouq ${ }^{1)}$ Dan Dwi Edi Setyawan ${ }^{2)}$ \\ 1,2) Teknik Komputer, Institut Teknologi Telkom Surabaya, Indonesia \\ email: ${ }^{1)}$ alfarouq01@gmail.com, ${ }^{2}$ dwi2edi@gmail.com
}

\begin{abstract}
Abstrak - Indonesia adalah salah satu Negara yang memiliki tingkat rawan bencana yang cukup tinggi. Mulai dari bencana alam, pembakaran hutan, dan lain-lain. Apabila terjadi bencana tersebut maka dibutuhkan penyelamatan yang segera sedangkan jumlah tim pencarian dan penyelamatan (search and rescue; SAR) terbatas dan beberapa tempat susah untuk dijangkau manusia. Dari permasalahan ini maka diperlukan robot untuk mempermudah dalam membantu penyelamatan korban bencana yang masih hidup dalam hal memberi informasi posisi. Sistem robot penyelamat dirancang dengan cross platform antara robot dan PC. Robot yang didesain memiliki thermostat sebagai pendeteksi temperatur, kemudian kamera untuk mendeteksi korban dan roda untuk bergerak. Robot akan dikendalikan tim pencarian dan penyelamatan. Robot akan menyisiri daerah bencana untuk menenukan korban yang masih hidup. Di dalam robot juga menggunakan algoritma Viola-Jones untuk deteksi muka. Hal ini digunakan untuk membantu menemukan korban yang masih hidup. Penyusuran untuk menemukan korban yang selamat pada umumnya membutuhkan waktu seharian, tetapi sistem yang telah dirancang dapat melakukannya lebih cepat yang mana meningkatkan kesempatan korban untuk hidup. Yang dimaksud masih hidup adalah korban yang masih bisa bangun, entah dalam keadaan duduk atau berdiri. Tingkat pengenalan wajahnya memiliki rata-rata galatnya $40,93 \%$ dengan keadaan dalam satu gambar memiliki berbagai objek lain termasuk jumlah korban yang banyak. Bila jumlah korban yang dideteksi dalam satu gambar hanya kurang dari lima maka galatnya dapat mendekati $0 \%$. Dengan tingkat galat tersebut sistem ini bisa diaplikasikan.
\end{abstract}

Kata Kunci: Desain Robot, deteksi muka, sistem penyelamatan

\section{Pendahuluan}

Indonesia menjadi Negara yang paling rawan terhadap bencana di dunia berdasarkan data yang dikeluarkan oleh Badan Perserikatan Bangsa-bangsa (PBB) untuk Strategi Internasional Pengurangan Risiko Bencana (UN-ISDR). Tingginya posisi indonesia ini dihitung dari jumlah manusia yang terancam risiko kehilangan nyawa pada saat bencana alam terjadi. Saat terjadi bencana maka datanglah tim pencarian dan penyelamatan. Tim pencarian dan penyelamatan sering kali kewalahan dikarenakan daerah bencana yang luas, susah untuk disisiri dan jumlah anggota yang terbatas. Dari permasalahan ini maka diperlukan cara atau sistem untuk melakukan pencarian korban yang masih hidup secara efisien.

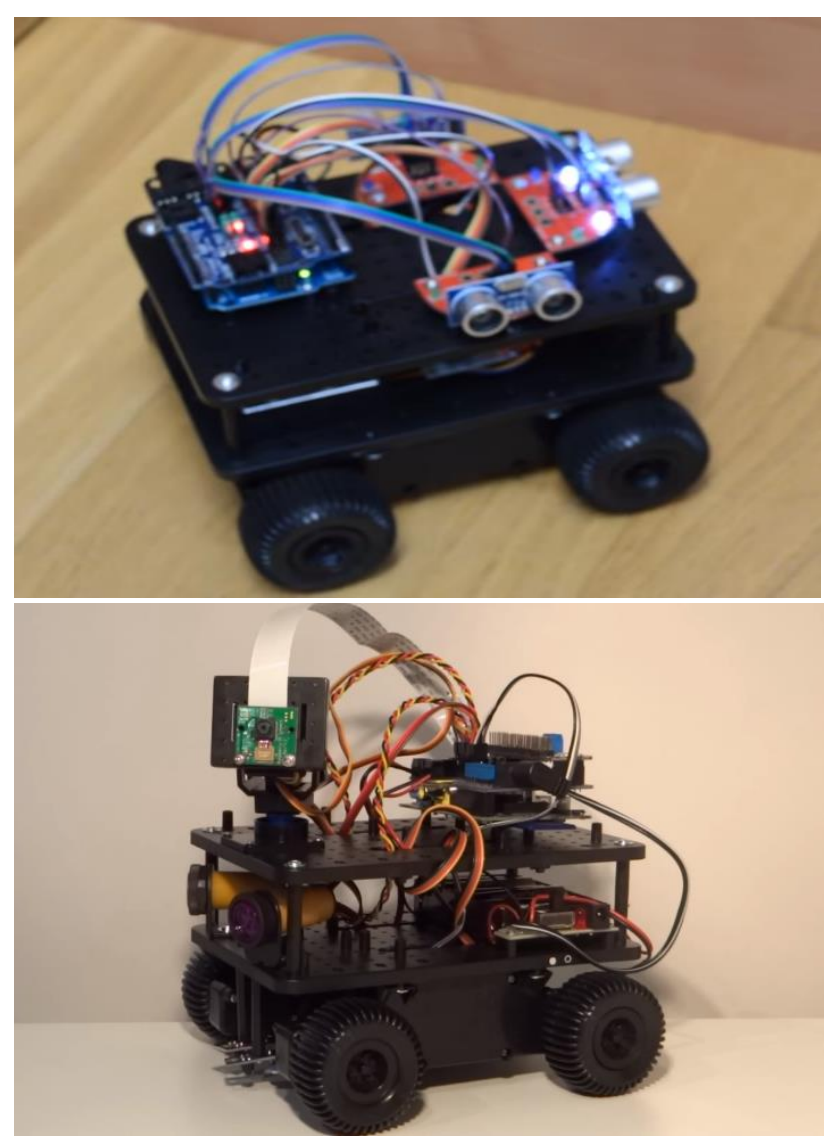

Gambar 1. Model robot yang dibangun

Untuk menyelesaikan masalah penyelamatan maka sistem yang dirancang adalah membangun robot yang memiliki tujuan untuk membantu mempermudah para tim pencarian dan penyelamatan menemukan korban bencana. Penyelamatan korban bencana yang dimaksud di sini adalah korban bencana yang ada di darat seperti kecelakaan kendaraan, bencana alam. Selain itu sistem yang dirancang juga bisa digunakan untuk menemukan sandera. Kemudian korban yang masih dalam keadaan hidup. Keadaan hidup yang dimaksud adalah ketika korban masih bisa bangun, entah duduk atau berdiri. 


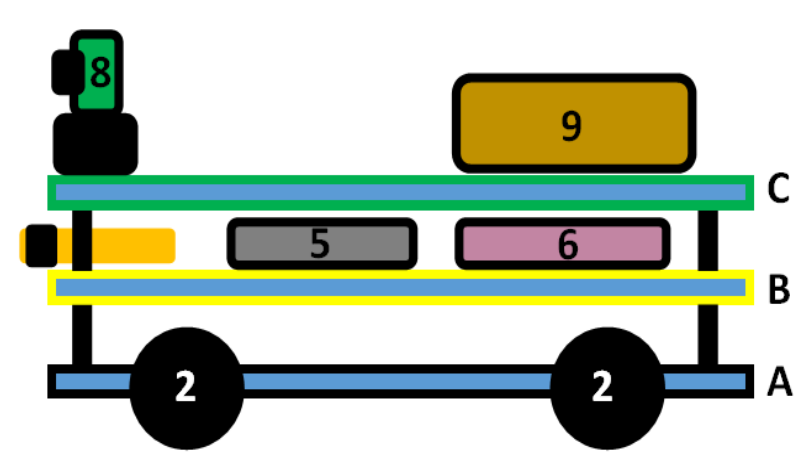

Gambar 2. Model dasar robot penyelamat, detail bagian di setiap nomor yang tertera terdapat pada Tabel 1

Teknologi pencarian dan penyelamatan sampai saat ini masih menggunakan teknologi lama seperti anjing pencari sedangkan perkembangan teknologi sudah berkembang. Maka pada sistem robot yang dibangun dilengkapi dengan sensor-sensor yang dapat membantu menemukan korban bencana yang masih hidup kemudian memberikan informasi lokasinya kepada tim pencarian dan penyelamatan. Model robot dapat dilihat pada Gambar 1 .

Robot ini hanya digunakan sebagai pemberi gambaran lingkungan sekitar dan lokasi korban kepada tim pencarian dan penyelamatan. Korban yang dapat dideteksi hanya yang berada di luar puing-puing. Korban yang dimaksud adalah seperti korban gempa, korban tanah longsor, korban kebakaran dan korban bencana lain yang berada di daratan kering. Oleh sebab itu tetap diperlukan anjing pelacak untuk menemukan korban yang berada di dalam puing-puing walaupun anjing tidak dapat memberikan gambaran umum tentang lingkungan fisik seperti robot yang dibangun. Sistem pendeteksian manusia memiliki jangkauan efektifnya maksimal 6 meter dengan menggunakan kamera VGA 2 megapiksel. Dilengkapi sensor api yang memiliki jangkauan 2 meter dan sensor jarak untuk mengetahui objek di depannya. Baterai hidup sekitar 2 jam pemakaian.

Keadaan terkini dalam robotika dalam hal penanganan bencana telah berkembang dan memberikan tinjauan umum teknologi yang sudah tersedia atau sedang dalam pengembangan. Selama beberapa tahun terakhir, teknologi robotika untuk respons bencana terus berkembang dan berbagai solusi robotik tersedia atau dalam pengembangan[1]. Oleh sebab itu tujuan dalam merancang dan membuat robot ini adalah untuk digunakan dalam misi tanggap darurat yang akan mampu menjelajah ke medan dan lingkungan bencana yang berbahaya bagi tim pencarian dan penyelamatan. Fungsi utama dari robot penyelamat yang dibangun adalah untuk mendeteksi korban yang selamat menggunakan transmisi video secara real-time dan mengirim lokasi robot melalui GPS Bluetooth yang dipasangkan pada robot. Kamera juga akan terhubung ke PC secara nirkabel untuk transmisi video secara real-time karena sistem yang real-time sangat penting[2,3,4]. GPS juga akan mengirim data lokasi ke PC dan akan memiliki lokasi di mana tim pencarian dan penyelamatan akan dikirim. Robot dikendalikan dengan Mikrokontroler dan akan dijalankan melihat gambaran di sekitar dengan video dari kamera yang terpasang pada robot. Dengan sistem robot ini maka dapat menjadi alat yang efisien untuk mempercepat operasi pencarian korban[5,6,7].

\section{METODOLOGI PENELTIAN}

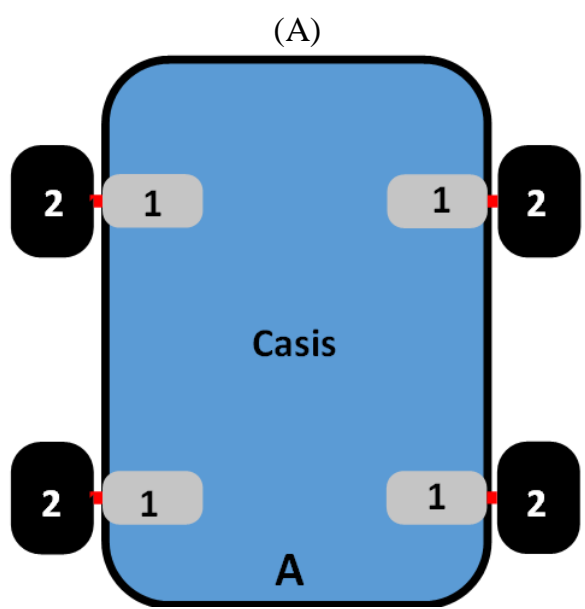

(B)

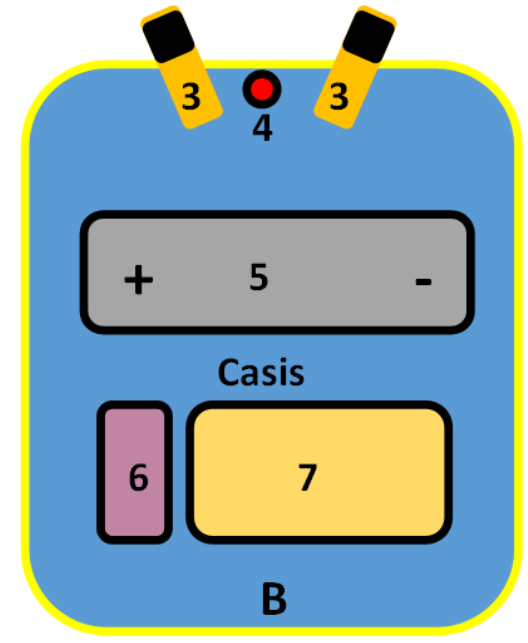

(C)

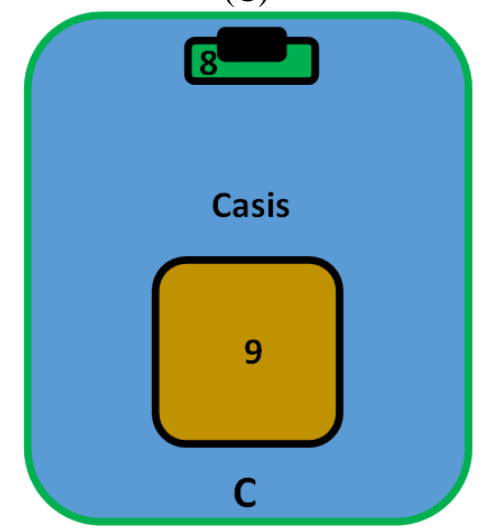

Gambar 3. Model detail di setiap casis dan perangkat robot dengan detail di setiap nomor yang tertera terdapat pada Tabel 1; (A) Casis paling bawah; (B) Casis bagian tengah;(C) Casis paling atas

Pada Bagian ini akan menjelaskan desain dan bagianbagian yang terdapat pada robot yang dibangun. Desain robot yang dibangun memiliki 3 bagian, yaitu casis A, casis B, dan casis C. Di setiap casis tersebut memiliki perangkat 
yang berbeda-beda tetapi saling berhubungan.

Tabel 1. Tabel Perangkat pada Robot

\begin{tabular}{|c|c|c|}
\hline $\begin{array}{l}\text { No. } \\
\text { Ref. }\end{array}$ & Nama & Deskripsi \\
\hline 1 & Motor & $\begin{array}{l}\text { Empat motor dengan spesifikasi } \\
\text { 500RPM dilengkapi rotary } \\
\text { encoder untuk menghitung } \\
\text { putaran motor. }\end{array}$ \\
\hline 2 & Roda Karet & $\begin{array}{l}\text { Empat roda yang terbuat dari } \\
\text { karet. }\end{array}$ \\
\hline 3 & Sensor Jarak & $\begin{array}{l}\text { Menggunakan ultrasonic atau } \\
\text { infrared sebagai pengenalan objek } \\
\text { yang terdapat di depan. }\end{array}$ \\
\hline 4 & Sensor Api & $\begin{array}{l}\text { Menggunakan thermostat untuk } \\
\text { mengetahui apa terdapat api atau } \\
\text { suhu di sekitar robot. }\end{array}$ \\
\hline 5 & Batrai Li-Po & Sebagai sumber tegangan robot. \\
\hline 6 & $\begin{array}{l}\text { Rangkaian } \\
\text { Sumber } \\
\text { Tegangan }\end{array}$ & $\begin{array}{l}\text { Digunakan sebagai menyalurkan } \\
\text { tegangan keseluruh perangkat. }\end{array}$ \\
\hline 7 & Sub-Pengendali & $\begin{array}{lrr}\text { Digunakan untuk } & \text { membaca } \\
\text { sensor-sensor dan } & \text { sebagai } \\
\text { pengendali robot. } & \text { Terdapat } \\
\text { Arduino UNO sebagai pengendali } \\
\text { dan dilengkapi GPS untuk } \\
\text { mendapatkan posisi robot. }\end{array}$ \\
\hline 8 & Modul Kamera & $\begin{array}{l}\text { Digunakan untuk menampilkan } \\
\text { gambar di sekitar robot }\end{array}$ \\
\hline 9 & $\begin{array}{l}\text { Pengendali } \\
\text { Utama }\end{array}$ & $\begin{array}{l}\text { Digunakan untuk memproses } \\
\text { pengolahan gambar dan mengirim } \\
\text { seluruh informasi sensor-sensor } \\
\text { ke komputer tim pencarian dan } \\
\text { penyelamatan. Dan menerima } \\
\text { perintah pengendalian robot dari } \\
\text { komputer tim pencarian dan } \\
\text { penyelamatan. }\end{array}$ \\
\hline
\end{tabular}

Pada casis A terdapat empat motor disertai encoder beserta roda. Encoder pada motor ini berfungsi untuk menghitung putaran motor yang telah terjadi. Kemudian pada casis B terdapat dua sensor jarak untuk mengetahui apabila terdapat suatu objek penghalang di depan robot, sensor api untuk mengetahui temperatur di sekitar robot, batrai Li-Po sebagai sumber tegangan, rangkaian sumber tegangan untuk mendistribusikan tegangan dari sumber tegangan ke perangkat lain, arduino uno sebagai subpengendali yang berfungsi sebagai perantara komunikasi antara sensor-sensor yang terdapat dengan Raspberry Pi, dan GPS untuk mengetahui lokasi robot.

Pada casis $\mathrm{C}$ terdapat modul kamera untuk mendapatkan gambaran di sekitar robot dan Raspberry Pi sebagai Pengendali utama robot yang digunakan sebagai pemrosesan gambar kemudian mengirimkan gambar dan hasil proses ke komputer tim pencarian dan penyelamatan beserta informasi sensor-sensor lain. Untuk detailnya terlihat pada Gambar 2.

Gambar 2 adalah model robot yang tampak dari samping kiri dan hanya terlihat beberapa perangkat. Sedangkan deskripsi di setiap casis dari Gambar 2 adalah pada Gambar 3. Sedangkan deskripsi detail di setiap perangkatnya adalah pada Tabel 1.

Pada Gambar 3 adalah gambaran letak perangkat di setiap casisnya. Kotak terbesar pada gambar tersebut adalah bagian casis, sedangkan kotak lainnya adalah perangkatperangkat yang terdapat di atasnya. Terdapat angka-angka pada setiap kotak tersebut. Angka-angka tersebut adalah angka referensi yang dijelaskan pada Tabel 1.

\section{HASIL DAN PEMBAHASAN}

Pada Bagian ini membahas tentang bagaimana proses setiap perangkat yang terdapat pada robot, cara kerja sistem yang dibangun, dan metode yang digunakan untuk mengenali manusia.

Proses di setiap perangkat yang terdapat pada robot adalah semua sensor-sensor yang terdapat (sensor jarak, sensor api / sensor temperatur) akan dikumpulkan di dalam Arduino UNO. Pada Arduino UNO juga yang mengendalikan motor driver untuk menggerakkan robot. Tidak hanya itu, informasi lokasi yang didapat dari modul GPS juga dikirim pada Arduino UNO. Kemudian data-data yang didapat dikirim melalui FTDI (Future Technology Devices International). FTDI adalah modul USB serial TTL(Transistor-Transistor Logic) yang berkualitas. FTDI akan mengirim data secara serial ke Raspberry Pi. Pada Raspberry Pi memproses data video yang diperoleh dari modul kamera. Proses yang dimaksud adalah untuk mengenali manusia. Setelah itu Raspberry Pi tersebut akan mengirim data seperti hasil video yang didapat, dan sensorsensor yang terpasang kepada komputer tim pencarian dan penyelamatan. Apabila telah menemukan korban bencana maka tim pencarian dan penyelamatan bisa langsung berangkat untuk melakukan operasi penyelamatan. Sedangkan robot bergerak dikendalikan dari komputer tim pencarian dan penyelamatan. Untuk detail gambarnya disajikan pada Gambar 4.

Sedangkan untuk proses penggunaannya adalah pada Gambar 5. Gambar 5 adalah proses bagaimana sistem berjalan dari robot dikendalikan oleh tim pencarian dan penyelamatan hingga tim pencarian dan penyelamatan mengirimkan timnya untuk melakukan operasi penyelamatan. Pada awal proses adalah pada tim pencarian dan penyelamatan untuk mengendalikan robot melalui komputer. 


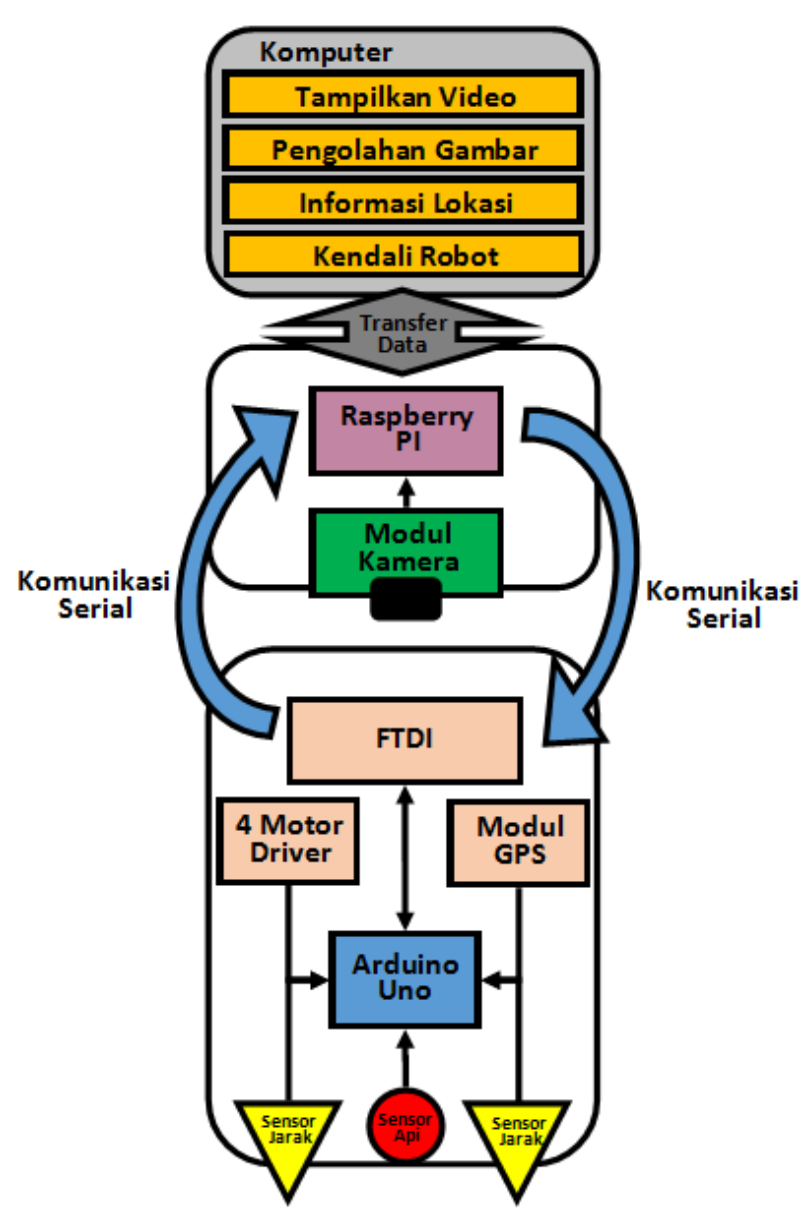

Gambar 4. Tabel diagram pada robot penyelamat yang dibangun

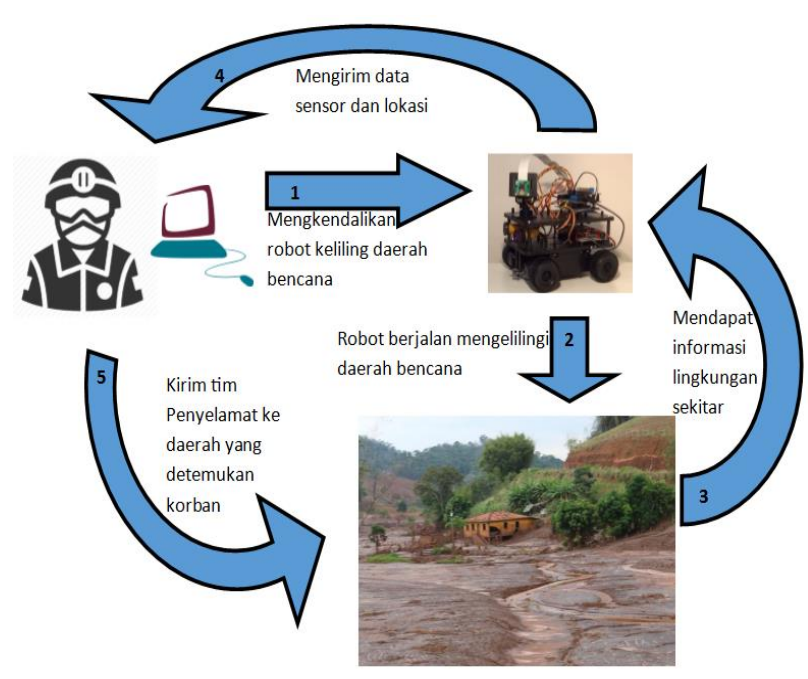

Gambar 5. Proses umum dalam menggunakan robot penyelamatan

Kemudian robot akan bergerak sesuai yang diinginkan pengendali ke daerah bencana. Dalam proses tersebut robot akan salalu memperbarui lokasi, gambar keadaan di sekitar robot, dan temperatur sekitar. Data akan dikirimkan melalui komunikasi tanpa kabel dengan menggunakan sistem User Datagram Protocol (UDP) ke komputer tim pencarian dan penyelamatan. Ketika robot dijalankan kemudian menemukan korban, maka informasi lokasi yang didapat dari robot dapat dijadikan acuan tim pencarian dan penyelamatan untuk segara dating pada lokasi tersebut.

Ketika robot bergerak menyisiri di daerah bencana, sistem pada robot akan melakukan streaming data gambar secara real-time yang didapat dari modul kamera. Pada modul kamera ini juga dilangkapi dengan mikrofon, sehingga audio akan terkirim secara bersamaan ke komputer tim pencari untuk diproses lebih lanjut. Kemudian pada robot dilengkapi algoritma sebagai detektor wajah. Jadi setiap gambar yang didapat akan diproses apakah terdapat wajah pada gambar tersebut. Jika ditemukan, maka akan mengirimkan pada titik posisi robot mengambil gambar bahwa pada di lokasi tersebut terdapat korban.

Banyak sekali metode yang digunakan untuk mengenali wajah. Pada dasar algoritma pendeteksian wajah menggunakan fitur tepi, karakteristik warna dari setiap piksel, fitur Haar, dan banyak lagi. Di sini sistem akan dibangun hanya menggunakan karakter warna dan fitur tepi karena sistem yang dibangun harus dapat berjalan real-time maka algoritma yang dibangun tidak harus banyak. Selain itu, sistem yang dibangun harus memiliki performa yang bagus.

Performa dari algoritma pengenalan wajah yang dievaluasi menggunakan terminologi berikut[8]:

- $\quad$ Tingkat deteksi. Jumlah wajah yang dideteksi dengan benar bergantung pada jumlah wajah dan klasifikasi yang telah ditentukan.

- Salah positif. Ini adalah ketika bagian gambar dideklarasikan sebagai wajah tetapi bukan.

- Salah negatif. Ini adalah ketika bagian gambar adalah wajah tetapi tidak terdeteksi.

- $\quad$ Salah deteksi. Salah deteksi $=$ salah positif + salah negatif.

Sistem deteksi wajah yang dibangun adalah mengklasifikasikan gambar berdasarkan peta nilai dari jenis fitur seperti Haar. Haar adalah fitur dari gambar digital yang digunakan untuk mengenali objek. Langkah pertama adalah penerapan fungsi yang mampu menghasilkan set fitur secara acak. Langkah kedua adalah realisasi dari algoritma peningkatan. Prosedur yang dilakukan adalah memberi sekumpulan klasifikasi sederhana, kemudian diuraikan pada bagian pembelajaran. Contoh bagian wajah yang benar dianggap positif dan yang bukan wajah dianggap negatif. Bagian wajah yang digunakan untuk pembelajaran bisa dibuat tiap sisi kepala. Langkah ketiga adalah realisasi kaskade, proses optimasi ini dirancang untuk mengurangi jumlah fitur yang digunakan dan sangat berguna untuk meningkatkan kinerja sistem. Langkah terakhir adalah menguji sistem pada data-data percobaan dan mengamati prilakunya dalam hal tingkat deteksi dan akurasi.

Pada algoritma selanjutnya adalah didasarkan pada deteksi kulit dengan cara mengambil warna dari gambar HSV. Kemudian mencari threshold warna kulit manusia yang sesuai, seperti pada Gambar 6. Pada Gambar 6 adalah batasan warna HSV dari masih banyak gangguan hingga tidak minim gangguan. 

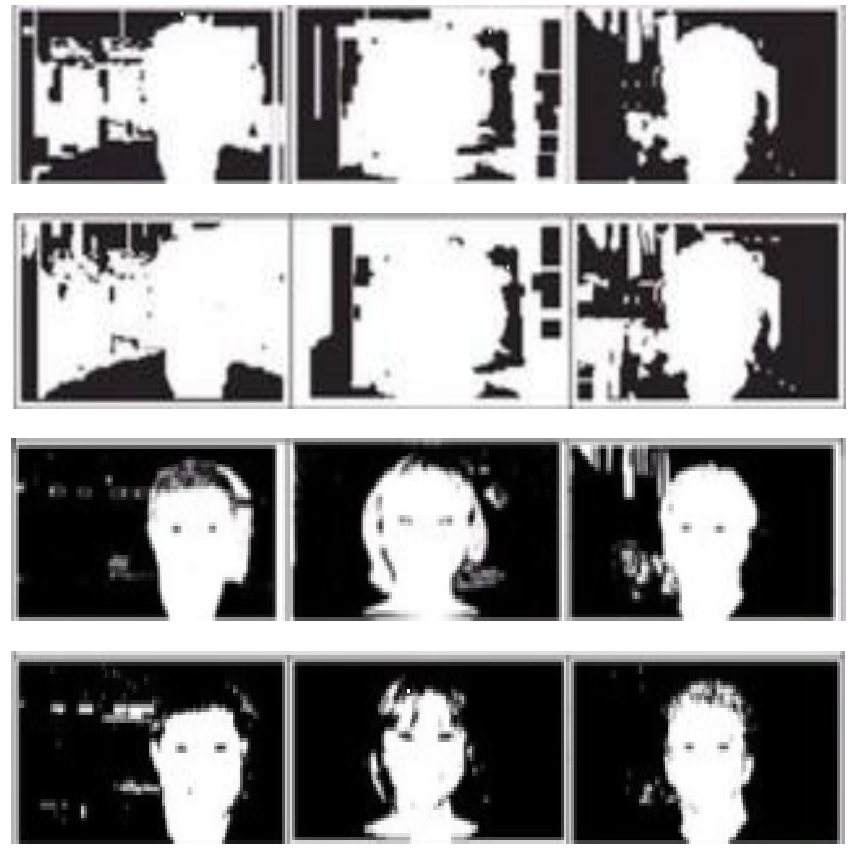

Gambar 6. Hasil percobaan untuk mendapatkan threshold warna kulit manusia dari HSV colorspace

Setelah mendapatkan warna kulit, selanjutnya adalah melakukan proses pembelajaran klasifikasi. Setelah itu akan mendapatkan daerah yang diinginkan. Keluaran klasifikasi adalah " 1 " jika daerah seperti yang diinginkan(dalam hal ini adalah manusia), dan "0" adalah sebaliknya.

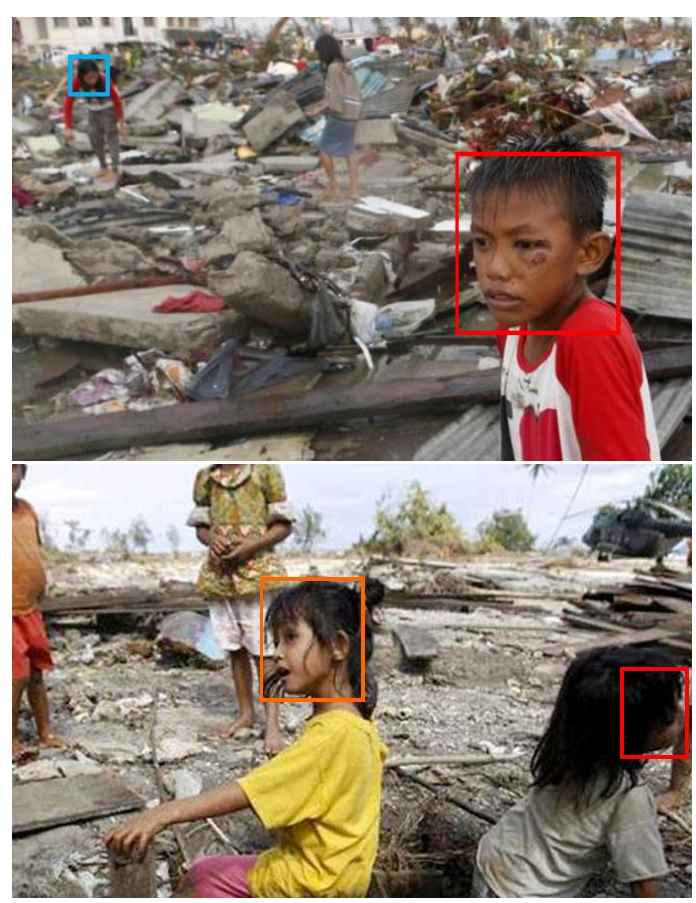

Gambar 7. Percobaan mendeteksi manusia
Tabel 2. Tabel Kesalahan

\begin{tabular}{cccccc}
\hline No & $\begin{array}{c}\text { Jumlah } \\
\text { Manusia }\end{array}$ & $\begin{array}{c}\text { Salah } \\
\text { Positif }\end{array}$ & $\begin{array}{c}\text { Salah } \\
\text { Negatif }\end{array}$ & $\begin{array}{c}\text { Salah } \\
\text { deteksi }\end{array}$ & Galat(\%) \\
\hline \hline 1 & 1 & 0 & 0 & 0 & 0 \\
\hline 2 & 2 & 0 & 0 & 0 & 0 \\
\hline 3 & 3 & 0 & 0 & 0 & 0 \\
\hline 4 & 4 & 0 & 0 & 0 & 0 \\
\hline 5 & 5 & 2 & 0 & 2 & 40 \\
\hline 6 & 6 & 1 & 1 & 2 & 33.33 \\
\hline 7 & 7 & 2 & 1 & 3 & 42.85 \\
\hline 8 & 8 & 2 & 1 & 3 & 37.5 \\
\hline 9 & 9 & 0 & 1 & 1 & 11.11 \\
\hline 10 & 10 & 2 & 2 & 4 & 40 \\
\hline 11 & 11 & 0 & 5 & 5 & 45.45 \\
\hline 12 & 12 & 5 & 5 & 10 & 83.33 \\
\hline 13 & 13 & 3 & 0 & 3 & 23.07 \\
\hline 14 & 14 & 5 & 6 & 11 & 78.57 \\
\hline 15 & 15 & 7 & 6 & 13 & 86.66 \\
\hline 16 & 16 & 7 & 4 & 11 & 68.75 \\
\hline 17 & 17 & 7 & 5 & 12 & 70.58 \\
\hline 18 & 18 & 6 & 3 & 9 & 50 \\
\hline 19 & 19 & 6 & 3 & 9 & 47.36 \\
\hline 20 & 20 & 7 & 5 & 12 & 60 \\
\hline & & & & &
\end{tabular}

Hasil percobaan ketika melihat manusia terlihat seperti pada Gambar 7. Posisi manusia yang diditeksi bisa dalam keadaan berdiri, duduk, atau tidur selama objek yang dilihat oleh robot memiliki karakteristik yang dianggap sebagai manusia(memiliki kepala/wajah). Sedangkan percobaan pengenalan dilakukan beberapa kali mulai pada gambar jumlah manusia yang seharusnya terdapat 1 manusia hingga 20 manusia. Kemudian dicari jumlah salah positif, salah negatif, dan salah deteksi. Kemudian salah deteksi tersebut dibandingkan dengan jumlah manusia yang benar untuk mendapatkan galat. Dari percobaan ini mendapatkan ratarata galat yang didapat adalah 40,93\%. Sedangkan untuk detail tiap galat yang didapat terdapat pada Tabel 2. Pada Tabel 2 terlihat ketika semakin padat atau semakin banyak jumlah manusia yang terdapat pada gambar yang diujicoba memiliki tingkat galat yang cukup tinggi. Hal ini terlihat pada Gambar 8.

Tingkat Galat

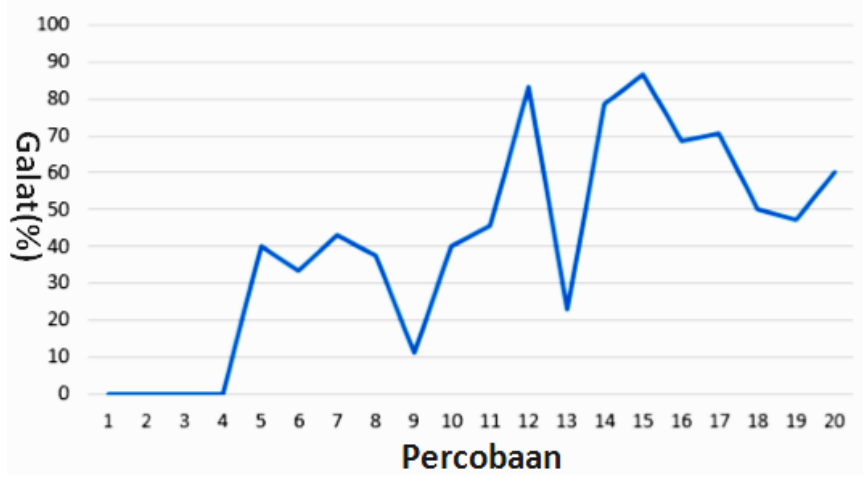

Gambar 8. Grafik dari tingkat galat percobaan pencarian wajah manusia berdasarkan Tabel 2

Ketika jumlah manusia lebih dari 10, terlihat galatnya cukup tinggi di atas 50\%. Walau terdapat beberapa gambar tersebut masih memiliki galat di bawah 30\%, seperti ketika jumlah manusia yang terdapat pada gambar 
adalah 13. Jadi galat juga tergantung pada keadaan gambar yang didapat. Semakin banyak gangguan seperti objek yang menyerupai manusia tapi bukan.

Galat yang didapatkan menggunakan Rumus (1). Di mana data salah deteksi( galat $\left._{d}\right)$ dibagi dengan jumlah manusia $\left(\mathrm{Jumlah}_{0}\right)$ kemudian dikali $100 \%$.

$$
g(\%)=\left(\text { galat }_{d} / \text { Jumlah }_{0}\right) * 100 \%
$$

\section{Kesimpulan}

Robot yang dibangun berfokus pada membantu tim pencarian dan penyelamatan dalam menemukan korban di daerah bencana yang susah atau tidak bisa dilalui oleh tim pencarian dan penyelamatan. Dengan sistem yang dibangun telah dapat diimplementasikan. Dengan sensorsensor yang telah terpasang pada robot, robot dapat memberikan informasi lokasi atau gambaran daerah bencana di sekitar robot. Daerah yang bisa disisiri oleh robot hanya daerah daratan. Dengan sistem yang dibangun membuat pekerjaan tim pencarian dan penyelamatan lebih efisien, karena di daerah bencana terkadang terbatasnya tim pencarian dan penyelamatan. Sehingga korba yang diselamatkan memiliki tingkat untuk hidup lebih besar. Sedangkan pada algoritma pencarian wajah untuk menemukan korban memiliki ratarata galat $40.93 \%$ yang didapat dari Tabel 2. Galat yang didapat sedikit besar, hal ini dikarenakan gambar yang terdapat di daerah bencana yang diuji coba banyak memiliki kesamaan dengan wajah.

\section{UCAPAN TERIMA KASIH}

Terimakasih disampaikan penulis kepada temanteman Institut Teknologi Telkom yang sudah membantu saran-saran dalam mengerjakan penelitian ini. Terimakasih juga kepada Yayasan Tinggi Pendidikan Telkom yang telah mendanai penelitian ini.

\section{Daftar Pustaka}

[1] Maurer, Johannes, et al. "TEDUSAR White Book-State of the Art in Search and Rescue Robots." Graz University of Technology, University of Maribor, Tech. Rep. (2014).

[2] Pramadihanto, Dadet, et al. "Merging of Depth Image Between Stereo Camera and Structure Sensor on Robot "FloW" Vision." International Journal on Advanced Science, Engineering and Information Technology 7.3 (2017): 1014-1025.

[3] Waskitho, Suryo Aji, et al. "FloW vision: Depth image enhancement by combining stereo RGB-depth sensor." Knowledge Creation and Intelligent Computing (KCIC), International Conference on. IEEE, 2016.

[4] Al Farouq, Ardiansyah, Raden Sanggar Dewanto, and Dadet Pramadihanto. "Transformed Stereo Vision and Structure Sensor for Development 3D Mapping on" FLoW" Humanoid Robot in Real Time." Journal of Telecommunication, Electronic and Computer Engineering (JTEC) 9.2-5 (2017): 129-133.

[5] Liu, Yugang, and Goldie Nejat. "Robotic urban search and rescue: A survey from the control perspective." Journal of Intelligent \& Robotic Systems 72.2 (2013): 147-165.

[6] Ning, Meng, et al. "Design, Analysis, and Experiment for Rescue Robot with Wheel-Legged Structure." Mathematical Problems in Engineering 2017 (2017).

[7] Burke, Jennifer L., et al. "Moonlight in Miami: Field study of human-robot interaction in the context of an urban search and rescue disaster response training exercise." Human-Computer Interaction 19.1-2 (2004): 85-116.

[8] Chen, Yao-Jiunn, and Yen-Chun Lin. "Simple facedetection algorithm based on minimum facial features." Industrial Electronics Society, 2007. IECON 2007. 33rd Annual Conference of the IEEE. IEEE, 2007.

[9] Casper, Jennifer, and Robin R. Murphy. "Human-robot interactions during the robot-assisted urban search and rescue response at the world trade center." IEEE Transactions on Systems, Man, and Cybernetics, Part B (Cybernetics) 33.3 (2003): 367-385.

[10] Davids, Angela. "Urban search and rescue robots: from tragedy to technology." IEEE Intelligent systems 17.2 (2002): 81-83.

[11] Baker, Michael, et al. "Improved interfaces for humanrobot interaction in urban search and rescue." Systems, Man and Cybernetics, 2004 IEEE International Conference on. Vol. 3. IEEE, 2004.

[12] Jacoff, Adam, et al. "Test arenas and performance metrics for urban search and rescue robots." Intelligent Robots and Systems, 2003.(IROS 2003). Proceedings. 2003 IEEE/RSJ International Conference on. Vol. 4. IEEE, 2003. 